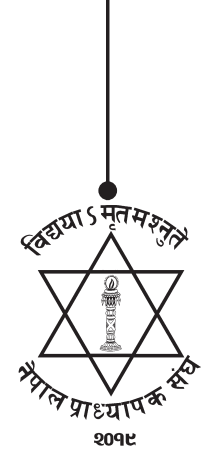

NJ: NUTA

\title{
Agricultural Transformation around Koshi Hill Region: A Rural Development Perspective
}

\author{
Tirtha Raj Timalsina \\ Lecturer, Dhankuta Multiple Campus, Dhankuta \\ Eastern Nepal \\ Email for correspondence:tirtha.timsina2@gmail.com
}

\begin{abstract}
Agriculture is considered to be the basic segment and the backbone of developing economy. In the same way it is a prime and domonent sector of Nepalese rural livelihood. By considering this fact, the true value of rural development lies on the rapid transformation of existing agricultural sector. The aim of this study is to analyze the role of agricultural transformation for rural development of Koshi Hill Region (KHR) of eastern Nepal. Both the primary as well as secondary data and information have been used to obtain the required findings. The study reveals the fact that agriculture is inevitable for rural people and its transformation is essential for the development of rural areas and the nation as a whole. Including primarily to the road network, the development of infrastructure can play the detrimental role to change the backward and rural scenario of this country.
\end{abstract}

Key words: Agricultural transformation, rural development, Koshi-Hill, essential, backbone, access.

\section{Conceptualization}

Agriculture is an important segment of traditional (feudal) economy, the transformation from feudalism to capitalism necessarily implies a transformation of agriculture (Lekhi, 2005). Thereby, agriculture is the prime occupation and also the backbone of most of the developing economies. The countries that are in the low profile of international comparision, no doubt they are moving on stagnat and backward agriculture with under or misutilized physical as well as human resources. The country which are backward and underdeveloped are not always facing the scarcity of resources but the techniques or to know how to manage the scarcely available means and reslurces is accepted as the principal understanding of development science. The most recent economic studies of the thirdworld show that earlier conclisions about third world development were wrong. Earlier studies concluded that the best development plan was to concentrate on industrialization, but newer studies show that agricultural development is just as important as, or more important than, industrialization (Todaro \& Smith, 2003).

Agricultural development deserves fundamental importance for the achievement of sustainable development and broad based economic growth, directly linked to food security and poverty reduction in case of developing nations like Nepal. The poor people of the remote areas are not only far from the 
access of governmental services but facing the lack of basic minimum necessities and are suffered by poverty and hunger. The Nobel Laureate in Economics, Gunnar Myrdal argued that it is an agricultural sector that the battle for long-term economic development will be won or lost (Lekhi, 2008). Trasitionally, the role of agriculture in economic development has been viewed as passive and supportive. Based on the historical experience of Western countries, economic development was seen as requiring a rapid structural transformation of the economy from one predominantly focused on agricultural activities to a more complex modern industrial and service society (Todaro \& Smith, 2003).

\section{Third World Agrarian System}

Two types of world agriculture are defined, low productivity and high productivity, and land productivity is compared for some developed and developing countries as an illustration of the difference. Asia, Africa, and Latin America are compared and contrasted in terms of the structure of their agricultural sectors. Latin American agriculture is characterized by the dualistic latifundio-manifundio system, in which a small fraction of low land owners own the great majority of cultivated land in the region. Total factor productivity is twice as high on family farms as on latifundios. Latifundios under-utilize labour, while manifundios overutileze labour, relative to land. The latifundios system persists partly because land ownership provides positive externalities, such as social status and political power (Todaro \& Smith, 1999). Prof. Schultz in his theory, "Transformation of Traditional Agriculture" states that there are three main attributes of traditional agriculture; farming is a way of life based on long established tradition, farming is the institutional set up which deals with the ownership of land, legality of tenureship and share of home consumption in agricultural production as well as traditional agriculture has some technical properties (Lekhi, 2008). On the basis of above attributes the farmers on traditional agriculture are compelled to stay as same as in the case of previous generations (Lekhi, 2005). W.W. Rostow in his theory "The Five Stage of Economic Growth" argued that traditional agriculture is the basic feature of traditional society which is preliminary phase of development and for the self sustainence and enter into Take-off stage (Lekhi, 2008). Here is why, agricultural transformation is a necessary part of the broader process of structural transformation, in which an increasing proportion of economic output and employment are generated by sectors other than agriculture. Thus this process is one way of attaining rural development since majority rural areas are engaged in agriculture.

Nepal is an underdeveloped and agricultural country situated between the emerging Asian giant nations (India \& China). The three ecological regions (i.e. Mountain, Hill and Terai) of the country have greater potentiality and possibility to transform agricultural system. The current population of this country is $26,494,504$. Among them 87 percent people are still in rural areas. According to census 2011, still 43 percent $(11,394,007)$ of total population are living in hill area of Nepal (Central Bureau of Statistics [CBS], 2011). The agricultural history of Nepal dates back to the earlier phase of civilization in various phases of ruling system such as Mallas, Lichhabi, Kirat, Shah and Ranas. People are used to adopt agriculture as a basic occupation for survival and till now it is as same as in the past couple of decades.

The basic causes of Nepalese agricultural stagnation is rely of the dominance of absentee landlords. Agricultural backwardness of the country is terrible due to the fact that those who are always passing their life in the farmland have no land, in contrary those who are always having the sufficient hectors of lands have not put their foot in the farmland. That means the real peasent are far from the 
ownership of land due to which the agricultural productivity is gradually deteriorating. On the same way uncontrolled migration and plotting of productive land nearby the road side for commercial purpose by the brokers further aggravates the problem of shortage and decline in agricultural production.

Agricultural dominancy is unavoidable fact of Nepalese economy, although its transformation and commercialization is not in the desirable pace. The share of GDP contribution is thought to be more than double than that of the existing contribution to maintain the demand of population who depend upon this sector. Devkota (2009) in his article pointed out that for the transformation of entire sociocultural and economic system in the country, agriculture transformation is necessary condition. Merely by means of agricultural transformation from subsistence to commercialized one, Nepal's development and social change seems to be possible.

\section{Research Objectives}

- To explore rural development and agriculture transformation activities around Kohi-Hill region.

- To appraise prospects and problems of agriculture transformation around Koshi-Hill region.

\section{Research Design}

For exploring agricultural transformation and rural development process around Koshi Hill region, I applied descriptive and exploratory research methods (Yin, 2003). Further, I used multiple case study research design in multisites (e.g. two village development committees [VDCs] from each district) to explore multiple programs (e.g. agriculture transfoprmation and rural development) through detailed in depth observation and conversations (Creswell, 2007). More specifically, I selected Parewadin and Pakharibas VDCs from Dhankuta District, Jarayotar and Deurali VDCs from Bhojpur, District, Chainpur and Mamlung VDCs from Sankhuwasabha District and Basantapur and Myanglung VDCs from Terhathum District. I conducted participant observation and key informat interview techniques for generating information in which key informants were selected purposively. Secondary data are collected from local level profiles, agriculture service centers and other related organization.

\section{Agricultural Transformation Practice in Nepal}

Koshi Hill region is one of the representative hill areas of Nepal. It represents the overall scenario of rural hill region and agricultural practive of this country. So the efforts and policies made for the national agricultural reform directly affects to the agricultural transformation and rural development of this region. Some of the recent efforts made by the government and other responsible authorities that are undertaken mainly after the restoration of democracy in 1990s are shown in the following points:

- After 1990, the multiparty governanment tried to introduce reforms in agricultural sectors;

- The yearly budget and the periodic plans of post 1990 outline the existing programs and introduce some new policies and strategies in this sectors;

- Various organizational frameworks are created such as; Ministry of Agriculture, Department of Agriculture, Regional and District level offices of Agricluture have established;

- Different research institute for agricultural transformation such as NARC, Pakhribas Agricultural Research Centre, Central food Lab, Crop Research Khumaltar etc. are established.

- Formulated National Agricultural Policy-2004 and National Agricultural Business Policy-2005;

- Implemented 20 years Agriclutural Perspective Plan to achieve a six fold increase in growth of agricultural income via (a) increase output growth and (b) decreased population growth. 
- A handsome amount of budget has started to allocate in periodic plan, such as $15.11 \%$ in $11^{\text {th }}$ Three year interim plan, $12.79 \%$ in $12^{\text {th }}$ three year plan in agricultural sector (NPC, 20011).

Increasing agricultural productivity is crucial for overall growth of the Nepalese economy and hence reducing poverty. Realizing this fact the government of Nepal has brought Agricultural Perspective Plan (APP) as a 20 years strategy for the agricultural development of the country. APP expects to achieve a six fold increase in growth of agricultural income per capita both via increase output growth and decrease population growth, which in turn act as an engine for development of the country and thus reduces incidence of poverty to 14 percent by 2017/18. The APP is an agricultureled growth strategy for poverty reduction and overall development of the country and has started with implementation of Nineth periodic plan (1997/98). APP envisaged achieving these twin goals without causing any revers effects to the environment. It aims at increasing the agricultural growth from the current rate of o.5-3 percent to 2.5-5.0 percent and reduces the poverty population from 49 percent to 14 percent over the 20 years plan period. It is expected that agricultural growth will also stimulate growth of non-agricultural sectors and the cumulative effects thus induced will help reduce poverty through an increase in income and generation of employment in agriculture and non-agricultural sectors (National Planning Commission [NPC], 1997).

\section{Rural Development around KHR}

Koshi Hill Area is constituated by the four district of Koshi zone of eastern Nepal. They are Sankhusabha, Terhathum, Dhankuta and Bhojpur whereas their total population is 606,192 (CBS, 2011). This region is situated in the mid-hill by which both the terai and mountain region of eastern part of this country is connected. Except Dhankuta, the development situation of each three district is comparatively poor, that may be due to the road accessibility and availability of other basic facilities. Dhankuta is relatively sound in education, infrastructure and socio-econimic development then that of others. Among them Dhankuta is famous for Orange and Chhintang, a place of historical importance, Terhathum is famous

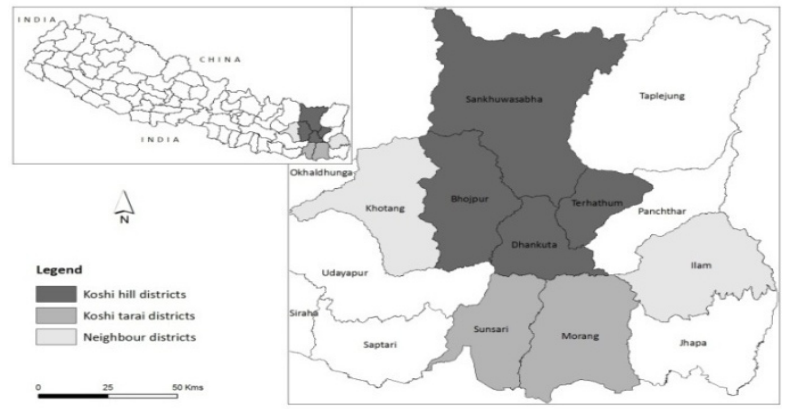

Figur1. Physical Structure of Koshi Hill Region in Dhaka Kapada and Tinjure Milke and Jaljale range, Sankhuwasabha is famous for Matsya Pokhari and Bhojpur is famous for Khukuri and Dingla Bazaar. However despite the specific importance of each of the district, the rapid change and commercialization in the occupation is not remarkable yet. It doesnot mean that there were no any effort for the development. A very famous and attractive practice of Integrated Rural Development Project was launched by covering the entire Koshi Hill region, namely Koshi Hill Area Rural Development Project (KHARDP) in 1979/80. This project has made some remarkable changes mainly in agriculture, transport, forestry, cottage induatries, heanth, education and local development. But unfurtunately this project has discontinued after the 8 years of its establishment. This region represents the majority of eastern hill region (Khatiwada, 2013). 
According to Khatiwada (2013), mainly after the construction of Koshi Highway in Koshi Hill region in the decade of 1980s which links this region to Terai, the traditional agriculture based closed economy has been changing to open market economy. The production system based on market demand induce people for crop intensification, diversification and commercialization by which the traditional subsistence based agriculture system of Koshi Hill gradually transformed to the palce of the production of competitive advantages and high value crops. This region is itself full of diversities due to which product variation is found in this region as well. The lower hill areas are mainly dominated by cereal crops whereas higher hill areas are famous for cattle grazing, herbs and tourism. Similarly, mid-hill is thought to be appropriate for horticulture and mixed farming system.

\section{Agricultural Transformation around KHR}

Koshi Hill region is constituted by joining four different districts of Koshi zone in eastern Nepal. It is said to be the Koshi region because each of these districts are connected with the same Arun River that is principal River of famous and the largest River of Nepal; Saptakoshi. Now each of the Districts are connected by road network which is considered as basic infrastructure of development. The agricultural commercialization and transformation really can play a prominent role for the development of this region. Although there are only two municipal areas in Dhankuta (Dhankuta) and Sankhuwasabha (Khandbari) district, this region is largely constituated by rural areas. Now days the rural areas of each of these districts are more commercialized and accessed with various new technologies, production methodology and even in the cultivation of highly commercialized crops and occupation in comparision to last few couple of years. That might be the result of active involvement of various local as well as outsiders NGOs and in the same way sufficient availability of conditional and non-conditional grants provided by the central government to the local governments.

Khatiwada (2013) argues that a lot of changes have been taking place with the introduction of new crops for market and it is the result ofindividual efforts, knowledge of agricultural inputs and use of technology. Now a day along with the commercial crops, livestock have become very important income sources because of its geographical conditions and distinctive ecological characteristics. The youth people of this region in these days are undoubtedly prefer to foreign employment as a convenient opportunities, along with this noticeable attraction of rural people has been going on the highly commercialized as well as alternative ways of agriculture rather than that of traditional. Some of the major modified and commercialized sectors and products are as follows:

- Small and Cottage Industries: Dhaka Kapada, Allo Production, Bhojpure Khukuri, Production of Copper and Kans (Bronz), Churpi Production, Tea Production etc.

- Valuable Medicinal Products: Alaichee, Rudrakshe, Chiraito, Haledo etc.

- Cash Crops: Potato, Tomato, Ginger, Garlic, Onion, Mango, Pear, Orange, Avocado, Lichee etc.

- Some Other Sectors of Occupation: Animal Husbandry, Bee Keeping, Poultry Farming, Hotel and Restaurant as well as Tourism related activities etc.

By the help of above mentioned occupation and products, the living standard of this region has been increasing every day. The household structure and purchasing power of people has also been changing rapidly due to which people are well accessed with health, education, communication and other public services. So there is no doubt, the real meaning of rural development does not prefer to search the livelihood by leaving the rural settlement and existing occupation but rather by living 
within the settlement with having proper and desirable improvement and transformation of existing occupation i.e. agriculture. The field study reveals that the agricultural transformation practice is more rapid in Dhankuta and Terhathum in comparision of Bhojpur and Sankhuwasabha. Vegitable farming and cash crops (which are perishable in nature) production are relatively more common in Dhankuta and Terhathum because of quick market access due to all season road networks but as a reasut of seasonality nature of the road networks in Bhojpur and Sankhuwasabha, the commercial cash crops with non-perishable nature such as beans, alaichee, rudrakshe, allo, chiraito and some other product of cottage industries are more common product for the market.

\section{Prospects of Agriculture Transformation around KHR}

- It is the prime source of occupation of rural people and still the main source of national income;

- It is the largest source of national revenue (35\%) in the GDP contribution;

- Nepal has the opportunity to get international trade through agricultural product;

- Sufficient availability of raw materials and primary basis for agro-based industries in this region;

- Rural industrialization may be possible in the Koshi Hill of eastern Nepal;

- This region is still full of the large unutilized natural resources.

These points specify that Koshi Hill regions has large potentialities for agricultural transformation by which overall development in general and rural development in particular is definitely possible.

\section{Problems of Agricultural Transformation around KHR}

This region in these days has been accessed with national road networks and electricity, but it is thought to be less than sufficient for the rapid development. That is due to the fact that including others both of these infrastructure are seasonal in nature. So people of this region are facing some basic problems for agricultural transformation and rural development. Some of the major problems are as follows:

- Traditional techniques of cultivation and seasonal nature of crops production;

- Lack of basic infrastructure such as road, irrigation etc;

- Poor market accessibility and declining per capita agricultural land;

- Uncontrolled migration and rapid capital flight and physical drain;

- Low access with modern agricultural technologies and tools;

- Lack of appropriate agricultural research and development etc.

The field study reveals that the farmers of this region are not resisting the change in agriculture. But they are willing to change and adopt the more productive technologies that make them more successful for agricultural transformation. Despite this fact some above mentioned problems are resisting the transformation practice and endeed rural development too.

\section{Conclusion}

Agriculture is a prominent and promising sector of Nepalese economy. This is similarly implies to the all most developing nations. Koshi Hill area is one of the segments of whole agrarian system of Nepalese economy. The details of the agricultural transform situation of this region are explained in the following sections. The backwardness of these countries seems to be the poor conservation and unscientific mobilization of agricultural sector. If the countries economy's development especially rural 
development should be takes place, then no doubt the agricultural transformation is not only the means but also the ends of developing nations. Transformation of agriculture can definitely plays the vital role for the development of backward and traditional rural sectors in Koshi Hill Region of eastern Nepal. Road linkage is considered as prime basis and indicator of transformation and urbanization of rural economy. In nutshell, it can be conclude that agricultural transformation is not only the necessary but the compulsion for the development of rural areas for which remarkable importance should goes on the proper management of infrastructure such as; road, irrigation, electricity, market and many more in this region.

\section{References}

Central Bureau of Statistics (CBS). (2012). National Population and Housing Census 2011. Kathmandu:

Chambers, R. (1983). Rural Development: Putting the Last First. New York: John Wiley and Sons, Inc.

Creswell, J. W. (2007). Qualitative inquiry and research design (2nd ed.). California: Sage Publication.

Devkota, F. R. (2009). Chepang Community and Agricultural Transformation in Nepal. Nepalese Journal of Development and Rural Studies, 6 (2), 23-35.

Khatiwada, S. P. (2013). Koshi Pahadi Kshetrako Bikaska Awasar ra Chunautiharu. Rupantaran, 1, 213-222.

Khatiwada, S. P. (2013). Reality Check of Bokre Village in Dhankuta District. Chintan-Dhara, 13, 235-244.

Lekhi, R. K. (2005). The Economic Development and Planning (10th eds.). New Delhi: Kalyani Publisher.

Lekhi, R. K. (2005). The Economic Development and Planning (11th eds.). New Delhi: Kalyani Publisher.

Ministry of Agriculture Development (MOAD). (2012). Statistical Information of Nepalese agriculture 2011/2012. Kathmandu: Author.

Singh, K. (1999). Rural Development Principle, Policies and Management. New Delhi: Vistaar Publication.

Todaro, M. P., \& Smith, S. C. (2003). Economic Development. Delhi: Pearson Education Inc.

Yin, R. K. (2003). Case study research: Design and method (3rd ed.). Thousand Oaks, CA: Sage. 